\title{
Cine y política en Alain Badiou: el poder retórico del cine al servicio de la trasmisión de la idea política del presente
}

\section{Cinema and Politics in Alain Badiou: The rhetorical power of cinema in the transmission of the political idea of the present}

\section{Wenceslao García Puchades}

Profesor del Departamento de Comunicación Audiovisual, Documentación e Historia del Arte en la Universidad Politécnica de Valencia

Fecha de recepción: 10 de noviembre de 2012

Fecha de revisión: 29 de enero de 2013

Para citar este artículo: García Puchades, W. (2013): Cine y política en Alain Badiou: el poder retórico del cine al servicio de la trasmisión de la idea política del presente, Icono 14, volumen 11 (1), pp. 195-215. doi: 10.7195/ri14.v11i1.554 


\section{Resumen}

El siguiente texto aborda la cuestión de cómo es posible pensar en el cine políticamente a partir de la obra del filósofo francés Alain Badiou. En él veremos que, aunque para este autor el carácter independiente y autónomo de la idea política y filmica nos impida pensar en un cine político, es posible pensar en un uso político del cine. Badiou, al igual que Platón en su día, le propone al militante político que para hacer más persuasiva la tarea de conseguir nuevas incorporaciones a su causa política, se apropie del poder retórico del cine.

\section{Palabras clave}

Comunicación - cine - filosofía - política - Alain Badiou

\section{Abstract}

The following text focuses on how it is possible to think politically of cinema based on the works of the French philosopher Alain Badiou. Through this text we will see that, even though for this author, the independent and autonomous character of cinema and political idea does not permit us to think of political cinema; however, it is possible to think of a political use of cinema. Badiou, like Plato in his day, suggests that political activists, in order to gain more followers to a political cause, put to use the rhetorical power of cinema.

\section{Key Words}

Communication - cinema - philosophy - politics - Alain Badiou

\section{Introducción}

Para el filósofo, matemático y novelista francés Alain Badiou el ámbito fílmico y el político comparten la misma capacidad de producir sus propias ideas singulares e inmanentes. Por un lado el cine es capaz de producir nuevas configuraciones formales a través del movimiento de sus imágenes-luz (Badiou, 2009c: 127-38); 
por otro lado, la política es capaz de producir nuevos órdenes legales a través de diferentes movimientos populares (Badiou, 2009a, 2009b). Sin embargo, esta coincidencia es precisamente la que nos impide concebir el cine cómo un ámbito que pueda producir ideas políticas. Ahora bien, aunque para Badiou el cine no puede producir ideas políticas sí que es posible hablar de un uso político del cine.

\section{Objetivos}

La intención de este artículo es proponer una salida a esta aparente imposibilidad. Tal y como argumentaremos en las siguientes líneas, para el autor francés las virtudes del cine no deben reducirse a su capacidad para producir sus propias novedades formales, sino que deben ampliarse a su capacidad de construir discursos retóricos capaces de afectar a las masas. Desde este punto de vista el cine podría ser usado políticamente si fuera capaz, por un lado, de construir a través de sus personajes fílmicos figuras retóricas contemporáneas capaces de favorecer la participación en movimientos políticos existentes y, por otro lado, de ofrecer al militante político figuras metafóricas que hicieran más comprensible la situación política del presente.

\section{Metodología}

Para la realización de esta tarea expondremos, en primer lugar, por qué para Badiou resulta imposible pensar en una idea que sea a la vez fílmica y política. Partiendo del estudio de sus textos, Teoría del sujeto (2008b), Compendio de metapolítica (2009a) y "L'Hypothèse du communisme" (2009b), trataremos de mostrar qué es para Badiou una idea política. A partir del estudio de sus textos fílmicos y artísticos expondremos qué entiende el pensador francés por una idea fílmica. Finalmente regresaremos nuevamente a sus textos fílmicos para argumentar de qué manera es posible sustraer de ellos un uso político del cine. Desde nuestro punto de vista, estos textos ejemplifican cómo el propio Badiou, militante maoísta en aquella época, se apropia de determinadas figuras retóricas del cine como instrumento didáctico para conseguir transmitir la idea política de su época.

DOI: ri14.v11i1.554 | ISSN: 1697-8293 | Año 2013 Volumen 11 N 1 | ICONO14 


\section{1. ¿Qué es una idea política?}

Para Badiou una idea política sólo se presenta con claridad al pensamiento en torno a un acontecimiento. Entendiendo por "acontecimiento" el aparecer de uno o varios actos que rompen con el saber dominante de una situación política histórica determinada y que obliga a posicionarse a cada uno de sus elementos respecto a él. El acontecimiento político estructura una situación social concreta de acuerdo a dos dimensiones: una dimensión lógica y una dimensión ética. En su primera dimensión los elementos de una situación política aparecen estructurados de acuerdo a una figura lógica disyuntiva que enfrenta a las lógicas políticas dominantes y a los nuevos movimientos emancipadores e igualitarios (verdades políticas). Esta figura puede devenir hacia una figura lógica oscura como consecuencia de la destrucción completa de su figura opuesta dando lugar a figuras totalitarias o reaccionarias. Por otro lado, en referencia a su dimensión ética, la situación política se estructura en las siguientes figuras discursivas: el discurso valiente del obrero precario que participa con coraje en movimientos emancipatorios y se opone, sin caer en discursos radicales, al discurso nihilista y temeroso del obrero que se deja llevar por las lógicas del mercado y la democracia parlamentaria.

Así vemos cómo, para Badiou, sólo el acontecimiento político tiene el poder de estructurar la totalidad de una situación social, condicionando, así, la tarea del militante político. Con otras palabras, el militante político en su tarea de buscar nuevas incorporaciones a la idea política del presente debe presentar sus figuras lógicas y éticas con claridad a partir de la existencia de acontecimientos. A este tipo de figuras Badiou les denominará "sujetos políticos". Un sujeto político es siempre una consecuencia formal y afectiva que se derivan de un acontecimiento. La tarea del filósofo consiste en identificar sus figuras fieles, reaccionarias y oscuras, para elaborar un discurso acerca la estructura del sujeto político del presente (Badiou, 2004a: 69-123; 2008a: 63-97; 2008b: 299-325; 2009a: 29-48; 2009b: 181-205).

Para Badiou la idea política no es ni una noción ni un concepto, sino la experimentación intelectual y afectiva de una hipótesis universal (a saber, la capacidad de los seres humanos de autoorganizarse de manera igualitaria) pero localizada. En la "L'Hypothèse communiste" Badiou formaliza el encuentro con la Idea a partir de las tres instancias del sujeto lacaniano: lo real, lo imaginario y lo simbólico (2009b: 187-92). Aplicado al ámbito político, el componente real se refiere a la secuencia

ICONO14 | Año 2013 Volumen 11 Nº 1 | ISSN: 1697-8293 | DOI: ri14.v11i1.554 
concreta donde aparece y desaparece una práctica y un pensamiento nuevo de la emancipación colectiva. Para Badiou esta práctica-pensamiento ha constituido la esencia del movimiento de la historia de la humanidad hacia la liberación del dominio del hombre por el hombre, de manera que puede ser considerada como un pensamiento universal —en la medida en que se fundan en principios igualitarios que podían ser compartidos por cualquiera - y eterno - en la medida en que sus principios pueden ser retomados una y otra vez a lo largo de la historia (Badiou, 2009a: 26-49; Lazarus, 1998; Toscano, 2004: 148). En resumen, el componente real de una idea política representaría la fuerza real de las masas para liberarse de las situaciones opresivas y autoorganizarse de manera igualitaria. Por otro lado, el componente simbólico de una idea, aplicado al ámbito político, hace referencia a la localización que muestra una secuencia de emancipación colectiva en el discurso simbólico de la historia: una forma local, que evidencia unas características espaciales, temporales y antropológicas particulares. El componente simbólico de una idea política consiste en la experimentación intelectual del carácter excepcional y particular de la fuerza emancipadora de las masas a través de un discurso particular. Finalmente, el componente imaginativo de una idea política se refiere a la experimentación por parte de un individuo de su capacidad de participar en una secuencia de emancipación colectiva a través de un discurso ético y afectivo. En conclusión, y tomando en cuenta los tres componentes de una idea, podemos definir una idea política como la operación subjetiva por la que un individuo experimenta a través de un discurso intelectual y afectivo que la participación en una secuencia política concreta supone participar en el movimiento histórico de la humanidad hacia su emancipación colectiva (Badiou, 2009b: 182-7).

Es dentro de este contexto donde se puede pensar el carácter genérico o universal de una política emancipadora particular. Su discurso muestra un aspecto paradójico en la medida en que la política de emancipación, por una parte, es esencialmente la de unas masas anónimas que carecen de significación para el orden simbólico establecido $\mathrm{y}$, por otro lado, se encuentra marcada por nombres propios que la identifican históricamente y la representan en su devenir simbólico (Badiou, 2009b: 197). Podríamos concluir este aparatado afirmando que, para Badiou, la operación subjetiva que constituye la incorporación a una idea política está mediada por la proyección discursiva de lo real político dentro de la ficción simbólica de la historia bajo la forma de una representación particular de la ac-

DOI: ri14.v11i1.554 | ISSN: 1697-8293 | Año 2013 Volumen 11 Nº 1 | ICONO14 
ción de las masas anónimas. La función de esta idea es, tal y como hemos visto, permitir la incorporación intelectual y afectiva a la disciplina de una secuencia de emancipación política mostrando que con ella se está participando en una causa universal y eterna.

\section{2. ¿Qué es una idea fílmica?}

En primer lugar es necesario afirmar que para Alain Badiou el cine es capaz de producir sus propias ideas artísticas, aunque sus operaciones hayan sido prestadas de otras artes (Badiou, 2009c: 127-38). De esta manera, y siguiendo la anterior caracterización de una idea política, es posible deducir qué entiende Badiou por una idea fílmica.

Una idea fílmica es la presentación discursiva de una situación cinematográfica estructurada en torno a un acontecimiento-cine. Entendiendo por "acontecimiento-cine" el aparecer de uno o varios filmes cuyas imágenes suponen una novedad radical con respecto al saber dominante de una situación fílmica determinada, de manera que obligan a posicionarse a cada uno de sus elementos respecto a él. El acontecimiento-cine estructura una situación fílmica de acuerdo una dimensión lógica y una dimensión ética. Respecto a la primera dimensión, una situación fílmica aparecería formalizada como una figura lógica de términos opuestos. Dichos términos designarían, por un lado, las operaciones fílmicas dominantes del cine comercial $y$, por otro lado, las nuevas operaciones fílmicas (verdades-cine) que tratan de oponerse a las operaciones anteriores. Al igual que en una idea política, una idea fílmica puede devenir hacia una figura lógica oscura como consecuencia de la destrucción completa de su término opuesto y dar lugar a figuras radicales (como sería el caso del "cine arte" ${ }^{\prime \prime}$ o reaccionarias (como sería el caso de aquellas propuestas fílmicas que acaban claudicando a las imposiciones de la industria). Por otro lado, en referencia a su dimensión ética, la situación política se estructura a partir de las siguientes figuras discursivas: el discurso valiente del cineasta que participa con coraje en nuevas creaciones fílmicas y que, sin caer en los discursos radicales de la búsqueda de un cine puro, hace frente al discurso nihilista y temeroso del cineasta que se deja llevar por los condicionamientos de la industria fílmica.

Así vemos cómo, para Badiou, sólo el acontecimiento fílmico tiene el poder de

ICONO14 | Año 2013 Volumen 11 Nº 1 | ISSN: 1697-8293 | DOI: ri14.v11i1.554 
estructurar formal y afectivamente la totalidad de una situación. De esta manera, la tarea del teórico del cine, a la hora de presentar las ideas fílmicas del presente, dependerá de la existencia de películas capaces de generar nuevas formas fílmicas y nuevos discursos heroicos que busquen transformar la situación del cine contemporáneo de acuerdo a las lógicas y los afectos que se derivan de un acontecimiento fílmico. A este tipo de películas Badiou les denominará "verdades-cine". Con otras palabras, una verdad-cine es siempre una consecuencia lógica y afectiva de un acontecimiento fílmico².

Tal y como Badiou expuso con respecto a la idea política, podríamos entender el encuentro de un individuo con la idea cinematográfica de acuerdo a un componente real, imaginario y simbólico. El componente real se referiría a la secuencia concreta de películas donde aparece una práctica-pensamiento novedoso sobre la configuración de las imágenes fílmicas ${ }^{3}$. Para Badiou esta práctica-pensamiento ha constituido la esencia del arte del cine a lo largo de su historia. Así, y de igual manera que el componente real de una idea política representaba la fuerza real de las masas para liberarse de las situaciones opresivas y autoorganizarse de manera igualitaria, el componente real del arte del cine representa la fuerza de las imágenes-cine para liberarse de la dominación del cine comercial e industrial y autoorganizarse mostrando la igualdad de las formas fílmicas. El componente simbólico, por su parte, haría referencia a la localización que muestra una secuencia de filmes post-acontecimientales concreta: una forma local que evidencia unas características fílmicas para una época y un lugar particular. Consistiría en el discurso intelectual mediante el cual un individuo experimenta una configuración de imágenes fílmicas como algo excepcional para la historia del cine. Finalmente, el componente imaginativo se referirá al discurso afectivo que le permite a un individuo experimentarse como un individuo capaz de incorporarse a un pensamiento artístico excepcional. En resumen, podríamos concluir este apartado afirmando que una idea-cine es el discurso intelectual y afectivo por el que un individuo se experimenta en afinidad con una configuración post-acontecimiental de imágenes fílmicas, en tanto movimiento del arte del cine a lo largo de su historia. 


\section{3. ¿Es posible pensar en un cine político?}

Visto desde esta perspectiva parece evidente que una idea fílmica nunca puede ser una idea política y viceversa. La razón se encuentra en su componente real. Mientras que la corporalidad de una idea política está constituida por las masas populares y obreras, la corporalidad de una idea cine se constituye por imágenesfílmicas.

Ahora bien, en nuestra opinión, aunque la teoría política y fílmica de Badiou no nos permite pensar en un cine político si que nos ofrece la oportunidad de pensar en él políticamente. Para ello debemos observar aquello que pueden tener en común el cine y la política, a saber, la identidad discursiva de su componente simbólico e imaginario. A través del primer tipo de identidad el militante político podría buscar en los filmes diferentes figuras retóricas análogas a la estructura formal de la idea política con el objetivo de que mediaran en su transmisión intelectual. A través del segundo tipo de identidad el militante político buscaría en los filmes personajes cuyos discursos tipificaran la estructura afectiva de una idea política con el objetivo de persuadir a las masas para su participación en ella. Así, el militante político, para realizar con eficiencia esta tarea, debe acudir al cine, no como dispositivo capaz de producir sus propias verdades, sino como dispositivo capaz de afectar a las masas. Veamos en qué medida Badiou considera al cine cómo un dispositivo capaz de afectar a las masas.

\subsection{El cine como dispositivo de masas}

Para Badiou, el cine es capaz de afectar a las masas porque presenta una ontología "impura" (2009c: 127-38; 2010a: 375-88). Ahora bien, el cine presenta esta impureza como consecuencia de un doble contagio: un contagio con las imágenes populares y con las nuevas tecnologías. Comencemos con el primero. Para el filósofo francés, la ontología del cine es una ontología impura porque su materia es sustraída de un ámbito no-cinematográfico, a saber, el ámbito fenoménico de las imágenes contemporáneas. Ahora bien, es precisamente esta impureza la que le otorga la virtud de poder dirigirse a las masas. Con otras palabras, las imágenes fílmicas se contagian de la imaginería común de manera que su contenido puede ser reconocido por una "humanidad genérica" o "popular" (Badiou, 2004b: 70; 


\section{0a: 377).}

Existe otra forma de contagio de la materia cinematográfica, de la que no habla Badiou en sus textos y que, desde nuestro punto de vista, también resulta fundamental para entender la capacidad del cine de ser de masas. Este contagio procede del ámbito tecnológico y de su aplicación al ámbito de la comunicaciones. Tal y como señala Stephen Keane en Cinetech: Film, Convergence and New Media, un filme muestra una notable convergencia entre la imagen cinemática y la tecnología que la presenta (2007: 1-2). De hecho, el modo en que el cine, hoy en día, converge con la televisión, el ordenador, Internet, los videojuegos y otros medios de comunicación digitales, pone en tela de juicio cualquier intento de adscribir al cine una esencia en relación al modo de distribución de los filmes. Para Keane (2007: 2) la evolución del cine siempre ha estado ligada al desarrollo de nuevas tecnologías perceptuales, desarrollándose, adaptándose y convergiendo con lo familiar pero siempre en constante renovación. Todo ello vuelve a poner en cuestión la pureza ontológica del cine, ya que su historia nos muestra que no existe un modo de convergencia único acerca la proyección de imágenes cinematográficas, sino diferentes dispositivos de proyección que han ido evolucionando a la par que lo ha hecho la tecnología posibilitando un consumo a gran escala.

En resumen, el cine ofrece a la filosofía la capacidad de seducir a las masas al permitir buscar en sus fábulas e imágenes populares el material para poder construir retóricas de la idea política. Ahora bien, para Badiou, estas fábulas e imágenes se encuentran principalmente en el cine comercial de masas. Es en este tipo de cine donde el militante político debe buscar el material didáctico adecuado para favorecer la transmisión formal y afectiva de la idea política. Los relatos populares y contemporáneos del cine le ofrecen la posibilidad de persuadir al mayor número de individuos, contribuyendo a hacer más efectiva dicha tarea. Así, el militante debe buscar en las fábulas e imágenes antes mencionadas dos tipos de figuras: por un lado, las figuras metafóricas que le permitan "introducir" el discurso formal de la "idea política" y, por otro lado, los "personajes de ficción" que le permitan "tipificar" los discursos afectivos que van asociados a dicha idea. En las siguientes líneas trataremos de exponer en qué medida los textos cinematográficos de Badiou ejemplifican estas dos tareas. 


\subsection{El cine como productor de figuras retóricas que representan}

\section{la estructura del discurso formal de la idea política}

Tal y como hemos argumentado en el punto anterior el militante político puede acudir a las fábulas e imágenes populares de los filmes comerciales para buscar instrumentos útiles para la transmisión intelectual de la idea política de presente. En este sentido, lo que realmente atrae al militante político, no es tanto el hecho de que estos filmes sean capaces de producir verdades, sino que respondan a otros dos aspectos: por un lado, que sean filmes de masas, de manera que sus imágenes populares puedan ser reconocidas por un gran número de personas; y por otro lado, que sean filmes que posean una estructura lógica análoga a la lógica de la "idea política". Subyace en esta tarea un uso didáctico del cine en la medida en que el militante político pone las imágenes del cine al servicio de la educación de una verdad que no es fílmica, sino política (Badiou, 2009c: 46).

Badiou ejemplifica este uso didáctico del cine en "Dialectique de la fable" (2003a). Para Badiou The Matrix (Larry \& Andrew Wachowski, 1999) ejemplifica, al igual que el mito de la caverna platónica, cómo aparece una verdad en el mundo de las opiniones. El mito de la caverna, al igual que The Matrix, nos muestra un universo engañoso, fabricado por sombras, con seres humanos esclavizados por esta ficción y con un grupo de individuos que se resisten a esta esclavitud y que pueden circular entre lo real del sol y lo aparente de las sombras. Pero la semejanza fundamental entre ambas alegorías subyace en el hecho de señalar que la operación de construcción de una verdad tiene origen en el interior del mundo de las opiniones como consecuencia de ser fiel a una ruptura con el orden simbólico establecido. Para Badiou ambas alegorías nos muestran que en el mundo de las opiniones sólo es posible aquello que es permitido por el régimen simbólico dominante, a saber, el régimen de lo relativo y lo particular. Es necesaria una ruptura con este régimen para poder pensar en lo imposible de la verdad universal. Esta ruptura aparecería de manera imprevista como una brecha en el sistema simbólico, como una disfunción. Esta brecha no sólo nos presentaría su ser contingente, sino un régimen simbólico genérico dirigido a cualquiera. De manera que únicamente permaneciendo fiel a este acontecer de lo genérico, es posible pensar en la construcción de lo imposible de una verdad dentro de lo posible del mundo de las opiniones. Veamos

ICONO14 | Año 2013 Volumen 11 Nº 1 | ISSN: 1697-8293 | DOI: ri14.v11i1.554 
con más detalle en qué medida The Matrix responde a esta estructura.

¿Qué es The Matrix? Para Badiou (2003a: 123-4) The Matrix está compuesto por tres componentes fundamentales. En primer lugar, existe un mundo supuesto en el que las máquinas han tomado el poder, reduciendo a los humanos al estado de meras larvas para obtener de ellos energía biológica. Hay pocas imágenes de este mundo que validen este postulado, ya que lo que interesa principalmente a los autores son los otros dos componentes. El segundo de los componentes es que las máquinas mantienen dentro de los cerebros de las larvas-humanas la ficción virtual de un mundo parecido a aquél que nosotros, los espectadores, conocemos y que también es aquél que en el filme ha desaparecido. El tercer componente nos plantea la idea de que existe un grupo de humanos que han logrado escapar de su estado de larvas y circulan entre el mundo "real" (el reino de las máquinas que absorben la energía a los humanos-larvas) y el mundo "virtual" (la "Matriz", es decir, el mundo que consolida artificialmente estos cuerpos). Finalmente, la acción del filme se organiza a partir de la lucha excepcional de un grupo de rebeldes contra el dominio de las máquinas. Para organizar su combate utilizarán una nave espacial que les permite circular dentro de lo "real", pero que también les permite introducirse en el mundo "virtual". Ahora bien, ¿quién es el elegido? ¿Quién puede participar en ese combate excepcional?: “En efecto, el elegido es aquél que sabe identificar lo aparente desde el interior de lo aparente - aquél que, dentro de la Caverna, consigue saber que las sombras no son mas que sombras" (Badiou, 2003a: 127).

Puesto en términos propios de la filosofía de Badiou: el punto crucial para poder participar en el procedimiento de una verdad es poder reconocer la paradoja de su acontecer. Este punto ha sido identificado por Badiou como la imposibilidad lógica del sitio del acontecimiento. El sitio del acontecimiento es concebido como el momento en el que el ser parecía bajo la forma de un agujero en su orden simbólico ${ }^{4}$. Ahora bien, esta aparición, en tanto ilegal, es efímera pues los aparatos del estado dominante tendían a ocultarla enseguida. Su reconocimiento como tal queda relegado al reconocimiento de su huella. La fidelidad a la huella del acontecimiento posibilita la participación en una verdad entendida como el "entre-dos" de un acontecimiento pasado y uno por venir (Badiou, 2007: 205-7, 234-5). Esta estructura subyace en el comienzo del filme. Lo "real" acontece de una manera imprevista en Matrix la primera vez que Trinity se le aparece a Neo y le dice: “The

DOI: ri14.v11i1.554 | ISSN: 1697-8293 | Año 2013 Volumen 11 Nº 1 | ICONO14 
answer is out there Neo. It's looking for you. And it will find you, if you want it to". El encuentro con Trinity, acontece en el orden simbólico de Matrix como una disfunción en el sistema. La "policía" — como diría Rancière (1996) - trata de restablecer rápidamente dicha disfunción tratando de eliminar las posibles consecuencias de este encuentro y estableciendo la normalidad de Matrix. Tal y como nos muestra la siguiente escena del filme todo parece haber sido un sueño. El acontecimiento "encuentro de Neo con Trinity" acabó, pero Neo sigue siendo fiel a sus huellas, a aquello que Trinity le dijo. De manera que cuando aparece Morpheus (segundo acontecimiento) y le da a elegir entre acceder al mundo real o permanecer en el mundo simulacral de Matrix, Neo acaba eligiendo lo primero.

Para Badiou estas escenas representan el modo en que se accede a una idea política. En el filme este hecho está representado por las acciones que llevan a cabo la tripulación del Nebuchadnezzer. Estas acciones provocan en Matrix nuevas rupturas en el orden simbólico (nuevos fallos en el sistema), a través de la cuales se consiguen nuevas incorporaciones a la causa revolucionaria. Cada una de estas incorporaciones representan el cuerpo-sujeto de una verdad política, un cuerpo infinito y siempre abierto a nuevas incorporaciones.

En resumen, ¿qué es The Matrix? The Matrix es una alegoría que nos permite entender que una idea política es un proceso que se lleva a cabo en el mundo del aparecer a partir del reconocimiento de sus verdades genéricas e inmanentes. Ahora bien, este reconocimiento pasa por ser capaces de identificar dicho acontecer como un impasse en la lógica dominante del aparecer, como una disfunción del sistema simbólico, como una "déception du voir" (Badiou 2003a: 129). Sólo es posible acceder a la idea política siendo capaces de reconocer el acontecer de sus verdades como rupturas inmanentes con el orden lógico de la meta-estructura estatal dominante. Badiou, por tanto, hace un uso táctico y mediador del cine en "Dialectiques de la fable": utiliza una ficción fílmica para seducirnos con la exposición de sus semejanzas con el concepto de "idea política" y así facilitar su incorporación intelectual.

ICONO14 | Año 2013 Volumen 11 Nº 1 | ISSN: 1697-8293 | DOI: ri14.v11i1.554 


\subsection{El cine como productor de "figuras tipo" capaces de transmi- \\ tir los discursos ético-afectivos de la idea política del presente}

En este apartado Badiou adopta el modo en que Platón expone su filosofía a partir del enfrentamiento de personajes que se encuentran "simétricamente" opuestos, sin que haya medida común alguna que permita mediar entre las posiciones que cada uno defiende. Platón encontró como modelo de esta operación el estilo narrativo teatral. A través de los personajes de sus Diálogos, el filósofo ateniense logra presentar "de un solo golpe" aquello que su argumento filosófico no podía sino exponer de manera sucesiva. Badiou denomina a dichos personajes con el término "ficciones típicas" o "figuras tipo" (Badiou, 2007a: 64)5. El filósofo francés encuentra en la construcción cinematográfica de ficciones a partir del enfrentamiento de personajes el sustituto del teatro en la filosofía de Platón. El cine, tal y como vimos, ofrece algo que el teatro no ofrece hoy en día, a saber, el poder de llegar a las masas.

Esta es la razón por la que hoy en día el militante político encuentra en el cine la mejor de las artes donde buscar personajes-tipo que le permitan representar el discurso ético y afectivo que va asociado a la idea política del presente. Esta estructura, tal y como argumentamos, estaría compuesta por el enfrentamiento de dos figuras afectivas tipo: la figura nihilista del discurso dominante de las opiniones - que se sostenía en la imagen del ser humano como mero animal guiado por la búsqueda de seguridad y placeres efímeros a partir de la lógica capitalistaparlamentaria; y la figura heroica del discurso excepcional de las verdades - que se sostenía en la imagen del ser humano como un ser valiente capaz de participar, punto por punto, en la creación de procedimientos justos. Ahora bien, también vimos como este discurso heroico corría el riesgo de evolucionar hacia discursos más suavizados — propios de figuras subjetivas reaccionarias-, y hacia discursos oscuros - propios de figuras subjetivas que obtienen su referente discursivo en formas nostálgicas del pasado.

Partiendo de este punto de vista, Badiou ejemplifica esta apropiación política de los personajes fílmicos en algunos de sus textos cinematográficos. En sus primeros escritos cinematográficos Badiou ejemplifica el uso del cine como instrumento táctico para aproximarse a la secuencia política verdadera de su época, a saber,

DOI: ri14.v11i1.554 | ISSN: 1697-8293 | Año 2013 Volumen 11 No 1 | ICONO14 
el movimiento revolucionario maoísta. Esta tarea se desarrollaría a la par que la elaboración de su Teoría del sujeto (2008b). El objetivo de Badiou en esta época consistía en trasladar la estructura teórica desarrollada en dicho texto a la situación cinematográfica post-mayo del 68 , para identificar qué filmes responderían a una ideología reaccionaria y qué filmes continuaban siendo fieles a la los axiomas maoístas. Esta es la tarea que realiza en su artículo de 1977 “Le cinéma révisionniste" $^{\prime \prime}$. En dicho texto Badiou analizará algunos filmes de los setenta tratando de identificar un cine contra-revolucionario. Así identificó este tipo de cine con aquellos filmes cuyos personajes tipificaban el discurso propio de una burguesía clásica, victimista y angustiada. Para Badiou el cine de Bergman ejemplifica a la perfección este modelo de cine (2010a : 64). Este discurso nihilista subyace también en algunos filmes de Kubrick, cuyos personajes, al igual que los de Bergman, "tipifican" una figura ética que se sustenta en la imposibilidad del ser humano para cambiar (64). Todos estos filmes tienen en común presentarnos a una nueva burguesía que se imagina en ascenso, postulándose a sí misma como heredera y legisladora de las luchas políticas populares del 68: "Nosotros somos esta inmensa masa de gente ordinaria y trabajadora" afirma el burgués (65). Aquí subyace el principio fundamental del cine revisionista: "que las masas son, para los nuevos burgueses, la materia de su proyecto, no su fuente; un rol, una fuerza sometida, y no un pensamiento creativo" (69). Para Badiou los filmes revisionistas relegan a un olvido el discurso del personaje popular revolucionario y cuando lo recuperan, lo hacen neutralizándolo de manera paródica o apelando a una "nostalgia provincial" (64).

La tarea que realiza Badiou en esta época consiste en identificar aquellos filmes cuyos personajes hacen frente al discurso nihilista del revisionismo político. Se trata de reconocer aquellas "figuras tipo" que ejemplifican un discurso ético con una serie de características. En primer lugar, se trataría de un discurso que estaría sustentado en una concepción del pueblo (campesinos y obreros) como creador efectivo de la historia y no como individuos nihilistas sometidos a su hedonismo. En segundo lugar, se trataría de un discurso que ubicaría al pueblo en el punto de vista de la resistencia y no de la opresión. Finalmente, se trataría de un discurso dividido en dos (el discurso del programa común del pueblo y el de los otros), alejándose del discurso único de la disciplina del partido comunista (65). En esto consiste la aproximación de Badiou al cine en los setenta: en la búsqueda de personajes cuyo discurso ético-afectivo tipifique un modo de hacer revolucionario al 
margen de los discursos obscuros del partido comunista y de los discursos nihilistas de los revisionistas.

A pesar de la distancia temporal, y consciente de que nos encontramos en una coyuntura política completamente diferente de la de los setenta, Badiou retoma la tarea iniciada en esta época en algunos de sus últimos textos cinematográficos. En "El fin de un comienzo", Badiou utiliza la película de Godard Tout va bien (1972) para presentarnos de una manera ejemplar las figuras discursivas políticas que se encontraban presentes en la revolución de mayo del 68: Montand y Fonda bloqueados en su rol de pequeño burgueses mediáticos, compañeros de ruta del PCF, el patrón de la fábrica, el "bonzo sindical", "la joven obrera violenta", "el viejo obrero reintegrado a la acción", "el maoísta establecido" (quien, conforme a las instrucciones de la Gauche Prolétarienne, no se manifiesta como tal) (Badiou, 2004b: 101-11, 109). Todas estas figuras aparecen articuladas por la contradicción, la dialéctica, la lucha entre figuras opuestas. Sin embargo, en medio de estos combates populares, no aparece ningún sujeto político verdadero. El título del filme, en su modo interrogativo, ya nos hace cuestionar este hecho: ¿Todo está bien? Los personajes del filme de Godard nos presentan la estructura discursiva política de comienzos de los setenta en Francia y el título la atraviesa señalando la necesidad de buscar una nueva figura subjetiva. Godard no nos presenta esta figura en ninguno de sus personajes, pero nos indica el vacío de donde partir, el fin de lo que fue un comienzo. Es tiempo de un re-comienzo.

En "Passion. Jean-Luc Godard", Badiou utiliza la película de Godard Passion (1982) para tipificar una estructura discursiva similar a la anterior. Al igual que en Tout va bien, Godard nos muestra a través de la situación de los trabajadores de una fábrica una especie de "pequeño microcosmos" que ejemplifica las relaciones entre la clase obrera y la patronal (Badiou 2010a: 263-77, 268). En lo que se refiere a la lucha de clases Godard la resumirá de manera burlesca a través de una persecución en la que un policía y el patrón son perseguidos por un obrero. Para Badiou este "microcosmos" representa el tratamiento ordinario de la cuestión de la lucha obrera. Nuevamente Godard parece repetir la estructura propuesta diez años antes en Tout va bien. Sin embargo, tal y como señala Badiou, esta vez el director francés nos presenta, en la ausencia de todo discurso político verdadero, una pregunta que, en lugar de paralizarnos, nos debe incitar a la esperanza: ¿será el movimiento "Solidaridad" de Polonia un referente a seguir? En 1982 Polonia representaba la

DOI: ri14.v11i1.554 | ISSN: 1697-8293 | Año 2013 Volumen 11 N 1 | ICONO14 
esperanza de un movimiento político obrero que trata de transformar su situación dominante (un país que por entonces se encontraba dominado por el partido comunista) sin caer en un capitalismo anárquico. Así lo expresa Badiou: "Passion es un filme que intenta captar esta "vía polaca" donde, finalmente, se diseña una alternativa real al capitalismo brutal y al socialismo dentro del movimiento obrero" (2010a: 271). Con otras palabras, Passion representa la estructura completa del discurso ético-afectivo que subyace a la situación política en Francia a finales de los ochenta: el discurso convencional del pacto de no agresión entre la patronal (Piccoli), los trabajadores (Isabelle Huppert) y el Estado (la policía), y el discurso revolucionario de la "vía polaca".

\section{Conclusión}

A lo largo de estas líneas hemos tratado de argumentar en qué medida es posible pensar en el cine políticamente a partir de la filosofía de Alain Badiou. Para ello ha sido necesario presentar su teoría fílmica y política. Así hemos visto como el filósofo francés entiende ambos ámbitos de acuerdo a tres componentes: el componente real, el simbólico y el imaginario. El componente real denota la corporalidad de su ámbito: las imágenes-fílmicas en el cine y los trabajadores en la política. El componente simbólico denota un discurso lógico acerca la estructura y la forma con la que aparece dicha corporalidad. Y el componente imaginario denota un discurso ético o afectivo acerca la concepción del ser humano. A parir de este enfoque Badiou elabora una teoría de la idea y la aplica al ámbito fílmico y político. Por un lado, una idea fílmica es el proceso subjetivo por el que un individuo adquiere conciencia de sí mismo como un cineasta valiente capaz de participar en la elaboración de un filme con una estructura formal novedosa e inclasificable según la lógica dominante de la industria. Por otro lado, una idea política es el proceso subjetivo por el que un individuo adquiere consciencia de sí mismo como un trabajador valiente capaz de participar en el desarrollo de un movimiento de trabajadores con una estructura organizativa alternativa a la lógica dominante de los colectivos sociales existentes (políticos, sindicales, nacionales, etc.). De todo lo expuesto se deriva dos enunciados básicos: el primero, el cine no es capaz de producir ideas políticas porque su ámbito de producción material es el de las imágenes fílmicas y no

ICONO14 | Año 2013 Volumen 11 Nº 1 | ISSN: 1697-8293 | DOI: ri14.v11i1.554 
el de las masas trabajadoras; y el segundo, el cine puede ser usado políticamente siempre y cuando sus discursos simbólico e imaginario contribuyan a la participación en las ideas políticas existentes. Así, en la exposición discursiva de una idea política, un militante político se puede apropiar, por un lado, de la estructura de fábulas e imágenes fílmicas que faciliten la comprensión de su dimensión formal o lógica, y, por otro lado, de personajes-tipo que representen la estructura de su dimensión ética o afectiva.

Ahora bien, ¿qué consecuencias se derivan de aplicar la teoría fílmica y política de Badiou al modo en el que la historia del cine ha entendido su relación con política y qué modelo de cine político contemporáneo legitimaría?

La primera consecuencia sería la crítica a aquellas teorías que consideran que el cine puede ser político siempre y cuando proponga una configuraciones fílmicas que escapen de la lógica representativa y narrativa del cine hollywoodiense. Esta teorías, derivadas principalmente del concepto de "distanciamiento" brechtiano y de su teatro radical, utilizan como referente el cine realizado por Bergson, Godard, los Straub o Pedro Costa, entre otros (Wals, 1974; Rancière, 2005: 143-6; 2010: 805; 2011: 130-2). En la actualidad quizás sea Jacques Rancière, uno de los principales defensores de esta concepción política del cine. Para este filósofo una película política "muestra su distancia con respecto al modo de circulación de las palabras, sonidos, imágenes, gestos y afectos en cuyo seno piensa el efecto de sus formas" (Rancière, 2010: 84). Desde este punto de vista el carácter político del cine vendría dado por una irresolución, una aporía visual, una tensión inclasificable entre lo representado fílmicamente y las formas de la experiencia (Rancière, 2011: 131). Sin embargo, tal y como ha quedado argumentado en este artículo, para Badiou, la tarea de producir rupturas con respecto a las formas sensibles conocidas no es propia del ámbito político, sino del artístico. Ahora bien, un militante político podría hacer un uso político de este tipo de rupturas utilizándolas como metáfora de la estructura lógica de una verdad política y favorecer así su comprensión: de la misma manera que el cine de Godard o los Straub producen nuevas configuraciones de imágenes fílmicas inclasificables por la lógica dominante hollywoodense, una verdad política se presenta como nuevas formas de organización social inclasificables por la lógica dominante del mercado.

La segunda consecuencia sería la crítica a aquellas teorías que denominan "político" al cine cuyo contenido versa sobre la política institucional (elecciones, per-

DOI: ri14.v11i1.554 | ISSN: 1697-8293 | Año 2013 Volumen 11 Nº 1 | ICONO14 
sonajes políticos, partidos, gobiernos, intrigas de estado, etc) (Christensen y Haas, 2005; Franklin, 2006; Coyne, 2008, Kellner, 2010; Flores Juderías, 2010, 2011). Tal y como hemos visto, para Badiou la verdadera política no es aquella que va asociada a las tareas realizadas por las organizaciones institucionales legitimadas por el Estado, sino aquella que va asociada a los diferentes movimientos de trabajadores capaces de auto-organizarse con independencia de éstas para transformar sus condiciones de precariedad laboral.

En tercer lugar, cabría hablar de una crítica a aquellas teorías que encuentran un carácter político en el denominado cine social o de denuncia propio de algunos documentales y del cine neo-realista y sus derivas contemporáneas. Películas recientes como Los invisibles (2010) de Marc Silver y Gael García Bernal, La cuadrilla (The navigators, 2001) de Kean Loach, Tocando el viento (Brassed 0ff, 1996) de Mark Herman, Reprise (1996) de Hervé Le Roux, o Marius et Jeannette (1998) de Robert Guédiguian, por citar a algunas, pretenden transformar subjetividades llamando la atención sobre injusticias sociales, actuales o del pasado, que tienen relevancia contemporánea. Sin embargo, si aplicamos la teoría política de Badiou, vemos como estas películas fracasan en el discurso ético que proponen, ya que en ellas se representa la figura obrera — verdaderos sujetos de todo movimiento político- como víctimas incapaces de transformar su situación de precariedad o como individuos paralizados por operaciones nostálgicas en un intento de recuperar una época que nunca volverá.

Ahora bien, según lo dicho acerca la teoría fílmica y política de Badiou, ¿qué tipo de cine contemporáneo sería el más adecuado para ser usado políticamente? Se trataría de películas en las que el obrero reaparezca bajo un nuevo discurso. Un discurso que los presenten como héroes contemporáneos: figuras ordinarias que por medidos precarios y alejados de todo sistema de representación institucional - sin hacer referencia a la lucha de clases o a una línea ideológica, política o sindical- son capaces de no ceder ante un estado de cosas; trabajadores que piensan las situaciones, deciden con autonomía y hacen posible pensar en lo imposible; sujetos valientes que a través de sus acciones transforman realmente el mundo y modifican fundamentalmente la imagen infravalorada que tienen de ellos. Un ejemplo de estas figuras las encontramos en películas como Recursos humanos (Laurent Cantet, 1999), Rosetta (hermanos Dardenne, 1999), La petite vendeuse de soleil (Djibril Diop, 1999) o The Big One (Michael Moore, 1998). Todas ellas tienen 
como protagonista a una héroe ordinario, un individuo valiente capaz de hacer frente a los miedos del mundo contemporáneo (la globalización, el desempleo, los cierres de fábricas, la fatalidad de las muertes por el sida, etc.). Sin embargo, estas películas no deberían ser denominadas "políticas", sino "didácticas", pues contribuyen a la enseñanza de un discurso ético que rompe con la opinión dominante y favorece la participación en ideas políticas. En definitiva, retóricas fílmicas que nos presentan el poder subjetivo de un individuo que, en el seno de una situación determinada, reivindica que sólo es posible la decisión libre y autónoma más allá de las ligaduras del mercado y la competitividad.

\section{Notas}

[1] Este cine-arte tendría su máxima expresión en las propuestas más experimentales del cine de vanguardia, el cual no es representativo del arte del cine (Badiou, 2010: 100). Para Badiou el cine-arte o experimental se caracteriza por aquello que caracterizó a la vanguardia artística de principio de siglo, a saber, "la pasión por lo real" (2005: 35). Esta invocación de lo real se fundamentaba en la pasión por lo nuevo sin contar con lo viejo. (57). Así, y dado que la destrucción completa nunca podía llegar, el siglo se mantuvo obsesionado con el "terminar" (172-3).

[2] Para Badiou una verdad en el arte es una configuración artística, iniciada por un acontecimiento (un acontecimiento es en general un grupo de obras, un múltiple singular de obras) y desplegada por azar bajo la forma de obras que son sus "puntos-sujetos" (2009c: 57-8).

[3] Badiou parte por tanto de una concepción materialista del cine en tanto movimientos de "toma y montaje" de imágenes-materia-luz. (2009c: 136). Esta concepción del cine la hereda de Gilles Deleuze y de sus "falsos movimientos", "globales" y "locales" de imágenes-luz, los cuales darán lugar "imágenes movimiento" e "imágenes tiempo" (Deleuze, 1984: 14, 40, 93-4).

[4] El sitio del acontecimiento es el lugar desde donde puede tener lugar una innovación estructural en la medida en que contiene elementos indiscernibles y misteriosos que son amenazantes para la estabilidad de la situación original. Por esa razón, es tarea del estado de la situación asegurar la normalidad de la situación inhabilitando su amenaza potencial. Para ello el estado etiquetará al sitio del acontecimiento con la marca "vacío" (Badiou, 2007: 195-200, 212; 2008a: 414-7).

[5] En esta "figura tipo" resuena con intensidad aquello que Deleuze y Guattari denominó "personaje conceptual". Tal y como estos filósofos exponían en ¿Qué es la filosofía?, los "personajes conceptuales" representan los movimientos del pensamiento filosófico de un autor en lo que se refiere a un problema filosófico o la creación de un concepto: “[...] los personajes conceptuales ejecutan los movimientos que describen el plano de inmanencia del autor, e intervienen en la

DOI: ri14.v11i1.554 | ISSN: 1697-8293 | Año 2013 Volumen 11 № 1 | ICONO14 
propia creación de sus conceptos" (Deleuze y Guattari, 1997: 65).

[6] Este artículo aparece publicado por primera vez en La Feuille foudre con el título de "Le Cinéma révisionniste. Synthèse, pour un bilan de films comme 1900, L'Affiche rouge, Mado, Le Voyage des comédiens, Le Juge et l'assassin, et d'autres, fats ou à venir". Posteriormente será reimpreso en el recopilatorio que Antoine de Baecque ha realizado de sus textos fílmicos y que ha titulado Cinéma (Cfr., Badiou, 2010a: 63-71).

\section{Referencias}

Badiou, A. (2003a). “Dialectique de la fable”. En A. Badiou, Th. Benatouil, E. During \& al. (Eds.), Matrix, machine philosophique. Paris: Ellipses, pp. 120-29. Reimpreso en Cinéma. Paris: Nova Éditions (2010, 307-21).

Badiou, A. (2004a). La Ética: Ensayo sobre la conciencia del mal. México D. F.: Herder.

Badiou, A. (2004b). Pensar el cine 1: imagen, ética y filosofía. Buenos Aires: Manantial.

Badiou, A. (2005). El siglo. Buenos Aires: Manantial.

Badiou, A. (2007). El ser y el acontecimiento. Buenos Aires: Manantial.

Badiou, A. (2008a). Lógicas de los mundos: El Ser y el acontecimiento, 2. Buenos Aires: Manantial.

Badiou, A. (2008b). Teoría del sujeto. Buenos Aires: Prometeo Libros.

Badiou, A. (2009a). Compendio de Metapolítica. Buenos Aires: Prometeo Libros.

Badiou, A. (2009b). "L'Hypothèse du communisme". En Circonstances 5. L'hypothèse communiste. París: Nouvelles Éditions Lignes.

Badiou, A. (2009c). Pequeño manual de inestética. Buenos Aires: Prometeo Libros.

Badiou, A. (2010a). Cinéma. Antoine de Baecque (Comp.). París: Nova Éditions.

Badiou, A. (2010b). La philosophie et l'événement. Entrevista con Fabien Tarby. París: Germina.

Christensen, T., \& Haas, P. (2005). Projecting Politics: Political Messages in American Film. Nueva York: M. E. Sharpe.

Coyne, M. (2008). Hollywood Goes to Washington: American Politics on Screen. Londres: Reaktion Books.

Deleuze, G. (1984). La imagen-movimiento. Estudios sobre cine 1. Barcelona: 
Paidós Ibérica, S. A.

Deleuze G. y Guattari, F. (1997). ¿Qué es la filosofía? 4ª ed. Barcelona: Anagrama, S. A.

Flores Juderías, C. (2010). “Cine y elecciones: El candidato como paradigma del género". En C. Rubio Pobes (Ed.), La historia a través del cine. Estados Unidos: una mirada a su imaginario colectivo. Bilbao: Universidad del País Vasco / Euskal Herriko Unibertsitatea, 125-155.

Flores Juderías, C. (2011). "Políticos, campañas, elecciones y parlamentos vistos a través del cine: una introducción". En C. Flores Juderías (Ed.), Retratos de una ambición (Políticos, campañas, elecciones y parlamentos vistos a través del cine). Valencia: Museu Valencia de la Il.lustració i la Modernitat, 7-20.

Franklin, D. (2006). Politics and Film: The Political Culture of Film in the United States. Lanham: Rowman \& Littlefield.

Keane, S. (2007). Cinetech: Film, Convergence and New Media. Basingstoke: Palgrave.

Kellner, D. (2010). Cinema Wars. Hollywood Film and Politics in the Bush-Cheney Era. Chichester: Wiley-Blackwell.

Lazarus, S. (1998). L'anthropologie du Nom. París: Le Seuil.

Rancière, J. (1996). El desacuerdo. Política y filosofía. Buenos Aires: Nueva Visión.

Rancière, J. (2005). La fábula cinematográfica. Reflexiones sobre la ficción en el cine. Barcelona: Paidós Ibérica S.A.

Rancière, J. (2010). El espectador emancipado. Castellón: Ellago Ediciones.

Toscano, A. (2004). "Communism As Separation". En Peter Hallward (Ed.) Think Again: Alain Badiou and the Future of Philosophy. Londres: Continuum. 138-49.

Wals, M. (1974). "Political formations in the cinema of Jean-Marie Straub". Jump Cut: A Review of Contemporary Media, 4, 12-8 